open 2 access

\title{
Health Behavior of Adolescent Smokers During Covid-19 Pandemic
}

\author{
Muria Helina $^{1 *}$, Novi Hendrika Jayaputra ${ }^{1}$, Sukri Palutturi ${ }^{2}$ \\ ${ }^{1}$ Department of Social Welfare, Faculty of Social Science and Political Science, Universitas Bengkulu, Bengkulu, Indonesia; \\ ${ }^{2}$ Department of Health Administration and Policy, Faculty of Public Health, Universitas Hasanudin, Makassar, Indonesia
}

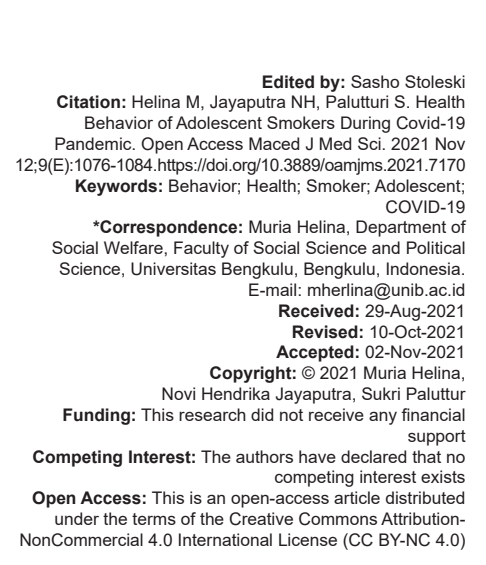

Abstract

AIM: This research aims to determine the health behavior of adolescent smokers during the COVID-19 pandemic.

METHOD: Both quantitative and qualitative analyses were conducted simultaneously using the design of " $\mathrm{t}$ " and Chi-square test through the distribution of questionnaires to 135 respondents as well as descriptive design and case studies, respectively. The data were collected by 13 informants through in-depth interviews, observation, and documentation.

RESULTS: The results showed that 5 out of the 6 indicators of the demographic characteristics were correlated to the economic pressure of the families of adolescent smokers which also correlates with their health behavior during the COVID-19 pandemic.

CONCLUSION: The increase in the price of cigarettes and family control are measures that regulate children from buying cigarettes.

\section{Introduction}

According to the World Health Organization, smoking is a public health problem, which is significantly harmful to all ages [1]. Every year, tobacco kills more than 8 million people worldwide, where over 7 million are due to the direct use of tobacco and approximately 1.2 million are through exposure to the smoke. A previous research has shown that the increase in the consumption of tobacco products among young people has become a public health problem in India [2]. This was influenced by tobacco products advertisement, which affected the decision and behavior of young people to smoke. Meanwhile, in Nigeria, smoking has caused a big burden for the young people and various determinants such as the economic pressures on the family, which increased due to the cost of smoking among both school-aged and out-of-school adolescents, which are also related to tobacco [3].

In terms of the number of smokers, Indonesia ranked third in the world with approximately 90 million active smokers, including children, which is currently increasing in number. One of the factors that cause the high number of child smokers is their easy access to cigarettes. Almost all stalls and shops sell cigarettes at low prices [4]. Meanwhile, further explanation stated by the Tobacco Control Support Center (TCSC) in Indonesia, the country produced cigarettes with an average of 338 billion cigarettes per year in 2015, while the average cigarette consumption in 2013 for each person was 12.3 cigarettes per day or each person smoke 369 cigarettes per month. In addition, the death rate of smokers in the world is predicted to reach 10 million people by 2030 and $70 \%$ of them come from developing countries [5].

The basic health research report that was conducted in 2018 (Riskesdas, 2018) stated that the percentage of smokers above the age of 15 years was $29.3 \%$ in 2017 , which increased by $4.5-38.8 \%$ in 2018 . In addition, Indonesian smokers consume an average of 12 cigarettes daily [6]. In 2016, the National SocioEconomic Survey showed that $13 \%$ of Indonesians spent their money on grains, while $13.8 \%$ was on cigarettes. Therefore, the expenditure on cigarettes exceeded other food needs such as eggs, which improve family nutrition. Furthermore, about 225,700 Indonesians died from smoking or other diseases related to tobacco [7]. Furthermore, cigarettes were the second most consumed commodity by the poor apart from rice, which is higher than other basic needs [8].

The chairman of the TCSC and the Association of Indonesian Public Health Experts stated that 
cigarette consumption in Indonesia is a concern. Moreover, cigarettes have several negative impacts on people's health and economy [9]. Research conducted in Jakarta discovered that smoking prevalence in the country showed an increasing trend. Therefore, when the smoking habit is not seriously handled, it can lead to an increased prevalence of drug abuse in the future, especially marijuana [10]. In 2016, the Indonesian population was 1.9 million people, where 495,992 were smokers among which $1.9 \%$ were children below the age of 18 years [11]. Meanwhile, the smoking habits of people aged above 15 years or a family members' smoking habit is one of the responsive predictors of toddlers' stunting and other diseases in Indonesia [12].

Bengkulu province on Sumatra Island is in the second position (32.31\%), after Lampung Province $(33.42 \%)$, of the highest smoking percentage among the population of age above 15 years old, which is still far from the national rate of $28.69 \%$ [13]. In Bengkulu Province, death caused by tobacco-related diseases reached 190,260 people. This showed that approximately $12.7 \%$ of all deaths were caused by smoking-related diseases [14]. Furthermore, it was shown that smokers in 2016 reached $26.52 \%$ and increased by $1.75 \%$ to $27.8 \%$ in 2018 , which is above the national average of $24.3 \%$.

One of the efforts made by the Bengkulu Provincial government to reduce the number of smokers is the collaboration with the Warrior Framework Convention on Tobacco Control of Bengkulu City and Regional Regulation (PERDA) Number 4 of 2017 concerning Non-Smoking Areas (KTR). However, all these efforts have not reduced the number of smokers because the Regional Regulation on KTR tends not to be implemented effectively in the Bengkulu City Government office [15]. Furthermore, research in Lebong Regency, Bengkulu Province, showed that smokers come from middle to lower economies. Meanwhile, the dominant factors that significantly influence smoking habits are family factors such as father, grandmother, and other family members [16]

This research is necessary because smoking is very dangerous for the health as well as the economy of the family and has spread to the age category of children and adolescents. Therefore, this research aims to determine the health behavior of adolescent smokers during the COVID-19 pandemic, because it has not been widely investigated. The general chairman of the Indonesian Doctors Association (PB IDI) stated that while there is no official research; active smokers can be more susceptible to Covid-19 because cigarette smoke enters the respiratory tract or throat. Hence, it is assumed it has the potential to transmit to others, when an active smoker is positive for COVID-19, by releasing virus droplets to people around [17].

This research aims to determine the health behavior of adolescent smokers during the COVID-19 pandemic.

\section{Methods}

In this research, a mixed-method was applied as it was considered more appropriate to be used at the same time. Furthermore, the quantitative method was conducted through the design of " $\mathrm{t}$ " and Chi-square test, while the qualitative research was conducted using a descriptive design and case studies. The mixed research uses different techniques in one phase simultaneously, which compliments each other in the acquisition of data. However, there are difficulties in obtaining complete and specific data using only a qualitative approach, since the data are in form of numbers. Meanwhile, the qualitative data were obtained in form of a narrative. Therefore, the two designs were considered appropriate to obtain a more specific result [18].

The correlation or sociodemographic relationship with the health behavior of adolescent smokers was analyzed quantitatively using the SPSS. Meanwhile, the main purpose of qualitative research is to understand social phenomena. This focuses more on a complete picture of the phenomenon, with the expectation of gaining a deeper understanding, such as health behavior in certain socio-cultural settings [19].

The data were collected qualitatively to determine the sociodemographic and the health behavior of adolescent smokers' correlation using statistical "t" and Chi-square tests, and the samples consisted of 135 respondents determined based on the Slovin formula with a set margin of error of $5 \%$ or 0.05 , using questionnaires. Furthermore, the respondents and informants were determined using the snowball technique, since they are adolescent smokers in every sub-villages of Bengkulu City. The sub-village involved was determined using a random sampling technique. Meanwhile, the qualitative data were obtained through in-depth interviews, observation, and documentation (the use of all three triangulation) [20] to all 13 information. To obtain data accuracy, focus group discussion technique was applied, in which there were 2 groups with 10 people each [21].

Furthermore, the data were analyzed using a combination of analytical steps approach [22]. First, a statistical test of SPSS was employed to determine the correlation between the variables. Then, the second method was to present data in a matrix table to determine the relationship between categories [23].

\section{Results}

Based on Table 1, there was a significant relationship between the age and health behavior of adolescent smokers in Bengkulu City, and this is proven through the chi-square value which was obtained to be 
99.578 with a $p=0.000$. This means that the increase in the age of adolescents is related to their health behavior towards smoking. There was a significant relationship between the first age of smokers and the health behavior of adolescent smokers with $p=0.000$, which indicates that the increase in the first age of adolescents smokers is related to their health behavior when smoking.

Table 1: Relationship between the demographical characteristics and economy condition of families and the health behavior of adolescent smokers during Covid-19 pandemic

\begin{tabular}{lllllll}
\hline & Age & $\begin{array}{l}\text { First } \\
\text { smoking }\end{array}$ & Education & $\begin{array}{l}\text { The initial } \\
\text { influence of } \\
\text { smoking }\end{array}$ & $\begin{array}{l}\text { Parents } \\
\text { occupation }\end{array}$ & $\begin{array}{l}\text { Economy } \\
\text { Condition }\end{array}$ \\
\hline Chi-square & $99.578^{\mathrm{a}}$ & $51.044^{\mathrm{a}}$ & $142.600^{\mathrm{a}}$ & $282.378^{\mathrm{b}}$ & $105.667^{\mathrm{c}}$ & $42.474^{\mathrm{d}}$ \\
df & 3 & 3 & 3 & 5 & 9 & 12 \\
Asymp. Sig. & 0.000 & 0.000 & 0.000 & 0.000 & 0.000 & 0.000 \\
\hline
\end{tabular}

Based on Table 1, it was known that there was a significant relationship between education and health behavior of adolescent smokers with a $p=0.000$. This indicates that adequate education is related to health behavior. This is in accordance with the following statement:

"My father and mother graduated from junior high school. The highest training currently at home is my sister, who graduated from SMA Negeri III Bengkulu. Our parents said that graduating from high school was already quite high" (HK, 17 years old, student of grade 12 of Senior High School). Subsequently, there was a significant relationship between the initial influence of smoking and the health behavior of adolescents with $p=0.000$. A significant relationship was found between parental occupation and the health behavior of adolescent smokers in Bengkulu City with $p=0.000$. This means that the parental occupation (higher income) is related to the health behavior of adolescent smokers. Furthermore, it was found that there was a significant relationship between economic conditions and the health behavior of adolescent smokers with a $p=0$, and this means that the increasing economic conditions are related to the health behavior of adolescent smokers.

The influence of health behavior of adolescent smokers in Bengkulu City used 5 indicators, namely maintaining health, illness behavior (IB), environmental health behavior, healthy behavior, and sick role behavior (SRB) on the economic pressure of adolescent smoking families during the covid-19 pandemic using simple linear regression analysis (Table 2 ).

Table 2: Relationship between health behavior and economy pressure of the family of adolescent smokers during Covid-19 pandemic

\begin{tabular}{|c|c|c|c|c|c|c|}
\hline \multicolumn{7}{|c|}{ Coefficients $^{a}$} \\
\hline \multirow{3}{*}{\multicolumn{2}{|c|}{ Model }} & \multirow{2}{*}{\multicolumn{2}{|c|}{$\begin{array}{l}\text { Unstandardized } \\
\text { Coefficients }\end{array}$}} & \multirow{3}{*}{$\begin{array}{l}\text { Standardized } \\
\text { Coefficients } \\
\text { Beta }\end{array}$} & \multirow[t]{3}{*}{$\mathrm{t}$} & \multirow[t]{3}{*}{ Sig. } \\
\hline & & & & & & \\
\hline & & B & Std. Error & & & \\
\hline \multirow[t]{2}{*}{1} & (Constant) & 21.834 & 4.799 & \multirow{3}{*}{0.347} & 4.550 & 0.000 \\
\hline & TOTAL HM & 0.770 & 0.180 & & 4.278 & 0.000 \\
\hline \multirow[t]{2}{*}{2} & (Constant) & 31.011 & 3.381 & & 9.173 & 0.000 \\
\hline & TOTAL_IB & 0.587 & 0.174 & \multirow[t]{2}{*}{0.279} & 3.366 & 0.001 \\
\hline \multirow[t]{2}{*}{3} & (Constant) & 30.059 & 3.838 & & 7.833 & 0.000 \\
\hline & TOTAL PKL & 0.734 & 0.229 & \multirow[t]{2}{*}{0.267} & 3.207 & 0.002 \\
\hline \multirow[t]{2}{*}{4} & (Constant) & 14.848 & 4.234 & & 3.507 & 0.001 \\
\hline & TOTAL PHS & 0.888 & 0.136 & \multirow[t]{2}{*}{0.490} & 6.515 & 0.000 \\
\hline 5 & (Constant) & 26.791 & 3.713 & & 7.216 & 0.000 \\
\hline
\end{tabular}

\section{Discussion}

The result shows that 70 smokers were at the age of above $15-18$ years old $(51.85 \%)$. Only a small percentage $(19.35 \%)$ of smokers reduced their tobacco intake during the COVID-19 pandemic due to fear of being exposed to covid-19 (2.47\%). The government has made efforts to reduce the consumption of cigarettes by enacting the Regulation of the Minister of Finance (PMK) Number 152/PMK.010/2019, regarding the excise rate on tobacco products with an increase of $21.55 \%$. These policies are expected to reduce the community power in the purchase of cigarettes as the anti-smoking policies, and the increase of cigarette tax effectively prevent migrant women from rural to urban behavior to start smoking. Furthermore, to control the smoking epidemic, low- and middle-income countries must increase the price of cigarettes. Otherwise, as stated by an economist from the University of Indonesia, based on the low price of cigarettes, this country has become a haven for baby or underage smokers [24], [25].

It was also found that the first age of adolescent smokers in Bengkulu City was 9-11 years old. The smoking behavior among adolescents was due to the influence of friends such as hanging out, school friends, and neighbors. The smoking habits in adolescents were influenced by parents, environment, peers, advertisements, as well as psychological and biological factors, including feelings of dependence on the hazardous substance [26].

This condition is supported by AD's statement, a 13 years old-junior high school student "Ambo pertamo merokok, ditraktir kawan sekolah, lamo-lamo ketagihan merokok, galak jugo ngambek piti ibu diamdiam untuk beli rokok, apo lagi kini covid sekolah libur dak dapek piti jajan,biasonyo ambo gunokan buek beli rokok" (At first, I was treated by school friends and then I was addicted to smoking for a long time. I often take my mother's money secretly to buy cigarettes. Moreover, during the Covid-19 holiday, I get pocket money, and therefore I usually use it to buy cigarettes). This is different from what happened in Lebong Regency, Bengkulu Province, in which smoking behavior was dominantly affected by the family since childhood. In this case, the smoker followed their father's smoking habit, in addition to another significant factor which is the behavior of previous ancestors that were smoking and being followed by the next generation [16].

In research conducted in Yogyakarta, two of the eight reasons youth do buy cigarettes are due to (1) The element of conformity to the model that advertises the product. The appearance of a model or a public figure as a brand ambassador for a cigarette is an indication that a fanatical fan will select a preferred product from the advertisement. (2) Trying more than two cigarettes of different brands, which is certainly based on the judgment from different advertisements [27]. 
The most of the parents of adolescent smokers in Bengkulu City were junior high school graduates $(81.85 \%)$, while the educational level of adolescent smokers was mostly $(35.05 \%)$ junior high school and $(34.85 \%)$ senior high school. This is in line with the previous statement, which revealed that a person's level of education/knowledge influences how he or she responds to external activities [28]. Furthermore, personality and education are important and independent factors related to smoking behavior in adolescents [29]. The higher parental upbringing was significantly associated with a lower risk of adolescents smoking regularly. As stated by AL, 17 years old, senior high school students. "I do not have much knowledge about covid-19. If I was recommended to apply health protocols. I will do it, even though it is not comfortable to wear a mask because it interferes with me while smoking and eating. I also often forget to wear a mask. I am currently still smoking, yet also worried and afraid of being exposed to covid."

Riau discovered that the first age of smoking is at the age of under 15 years old, the majority of which were Malay ethnic groups (48.3\%), with the influence of being invited by friends to smoke [30]. Furthermore, racism is associated with smoking behavior from early adolescence to early adulthood, regardless of gender, ethnicity, or socioeconomic circumstances, proving that racism should be viewed as an important social health determinant throughout life [31].

An 18 years old senior high school student, and 10 years old elementary school student, stated that "I am from Bengkulu Malay tribe. I first smoke at the age of 10, and I was influenced by my friends when we hang out. I was smoking secretly because I was afraid of being caught by my family, and I have been addicted to smoking until now. It is uncertain for a day, but I smoke about 8-10 cigarettes most often. The most important thing for me is to smoke and drink coffee while eating rice is not a problem. However, since I am currently afraid of being exposed to Covid-19, it is slightly reduced by 5-7 cigarettes per day"

This statement is supported by the opinion of the chairman of Quit Tobacco Indonesia, Yayi [32] that the Covid-19 pandemic could be the first step for smokers to strengthen their intention to quit, as smoking increases the risk of transmission of the virus and this will exacerbate the complications of the disease caused by Covid-19. The chance of being exposed to Covid-19 by adolescent e-smokers is greater and more dangerous for the users of e-cigarettes and regular cigarettes [33]. Smoking habits are not only harmful to their health, but also other family members. In addition, the purchase of cigarettes made by the head of the household has an impact on reducing household spending in terms of providing food, education, and health [34].

An Indonesian pulmonary doctor (PDPI), Agus Dwi Susanto in a written statement in Jakarta, stated that cigarettes addiction is dangerous to human health since smokers will be exposed to the threat of cancer 13 times higher than non-smokers [35]. When cigarette addicts are exposed to cancer, it will cost more money. Meanwhile, the job of the head of the family during the covid-19 pandemic is not fixed. "My father used to work in a coal mine, but he was laid off 6 months ago because the company suffered losses as a result of the COVID-19 pandemic. Now, he does any kind of work and his body became thin. Therefore, to relieve stress I hang out with my friends to play games and was treated by my friends to smoke" (AL, high school, 17 years).

This result is not much different from India [2], which found that the increase in consumption of tobacco products among adolescents is influenced by advertising and the social environment, leading to adolescents smoking regardless of family income. Tobacco packaging uses logos, colors, and images to create desired connotations that promote and enhance smoking, to catch people's interest [36].

According to the National Socio-Economic Survey in 2016, $13 \%$ of Indonesian expenditure was allocated to grains, while $13.8 \%$ was for cigarettes. Meanwhile, Hasbullah, the general chairman of the National Commission for Tobacco Control, urged every family to free their members from the dangers of the Covid-19 virus [37]. The trick is to stay at home and avoid smoking cigarettes. Furthermore, cigarettes are second to rice in terms of spending by most of the poor in Indonesia, and its demand is also higher than other basic needs [8]. This means that in terms of the economic condition of a family, the need to buy cigarettes is second, indicating that it is very important. "Yes, it is true that I come from a poor family which earns IDR 50,000 - 75,000 per day, and it is for buying cigarettes and for my mother. I usually smoke 10-12 cigarettes a day. Even though there is a Covid-19 pandemic, I smoke as usual. I have a fear of being exposed to Covid-19, but if I do not smoke, I lose my enthusiasm for work" (DV, high school, 17 years). This condition corresponds to the following statement, although there is the COVID19 pandemic, in which $77 \%$ of the poor did not reduce their cigarette consumption from January to February 2021 [38].

Regarding smoking behavior during the Covid19 pandemic, which shows that the percentage of smoking at home, at work, and other places, is almost the same at $47.3 \%$, and with more than 6 cigarettes per day of about $53.6 \%$ [39]. The reasons for continuous smoking may be due to anxiety, panic, and stress, as many as 45 respondents $(40.2 \%)$ and lack of activity (17.9\%). From a behavioral economic point of view, increasing the rate of cessation will require changes in the benefit-cost ratio of smoking, nicotine-boosting effects, and costs of smoking which are discussed among smokers with and without schizophrenia, depression, and interventions that reduce the efficacy of nicotine boosters and increase the cost of smoking [40]. Subsequently, higher cigarette prices provide more 
health and financial benefits for the poor by $20 \%$. Higher excise taxes support sustainable development goals related to noncommunicable diseases, poverty, and provide financial protection against disease [41].

Health maintenance (HM) has a significant and positive effect on economic pressure (TE), suggesting that the TE on adolescent smokers in Bengkulu City increases as HM increases, as shown in Table 2.

The results in Table 2 are supported by the statement of DB, 18 years old, senior high school student, "since I am the eldest child, my mother is very busy with my 3 younger siblings, and therefore she rarely pays attention to my health condition. She mainly controls my eating and clothes. Since my mother and father do not control me and I normally go home from work at a late hour, I normally use my free time to smoke in my room or the shop." Lisda further revealed [4] that efforts to reduce the prevalence of child smokers are not only the task of the government, all elements of society need to play an active role, comply with regulations, and be committed to enforcing supervision, not only by the government but also by the community and families.

The results showed that $52.60 \%$ did not want to stop smoking during the Covid-19 pandemic, on the ground that their weak bodies were not enthusiastic about school and work and not concentrating on school. They also think that exercise and a healthy diet are no more important than spending school fees on buying cigarettes (42.23-55.56\% of 135 respondents). This is supported by AS informant, a 17 years old senior high school student. "I have been smoking for 3 years and it is hard to stop. However, during the Covid-19 era, I avoided smoking with my friends and I currently only smoking 6-8 cigarettes a day, which was previously more than 12 cigarettes." This is not much different from studies that were conducted in the United States, in which about $70 \%$ of smokers in the US visit a primary care physician each year, providing an opportunity for effective cessation that is smokers are significantly more likely to try to quit smoking if tobacco treatment is beneficial [42].

These results confirm the widespread importance of smoking cessation among cancer survivors. In the US adult population suffering from cancer, the prevalence of smoking is currently higher in people with smoke-related cancer (RS) than in people with non-smoking-related cancer. Although smoking cessation interventions are essential for all cancer survivors, special efforts should target SRC sufferers [43]. In accordance with the statement of the Head of Bengkulu City Health Office, that the regional regulation on no-smoking areas (KTR) in Bengkulu City Government office has not been effectively enforced, cigarette advertisements are still enforced [15].

IB has a significant and positive influence on economic pressure (ET), and an increase in IB increases economic pressure on families of adolescent smokers
(Table 2). The main factors that influence the intention to quit smoking need to be determined for smokers that have little or no intention to quit. This is according to previous research [44], in a small group of young adults, office workers, and participants in various smoking cessation programs at health care centers. According to $\mathrm{DB}$, a 16 years old junior high school student, in a small group of young adults, office workers, and participants in various smoking cessation programs at health care centers. According to DB, 16 years old junior high school student, "Quitting smoking depends on one's intentions. I stopped smoking a year ago because I had a bad cough. I intended to stop smoking because I cannot hold it when my chest hurt due to coughing. However, 5 months ago I smoked again, although only 2-3 cigarettes per day." Furthermore, people with depression are more likely to smoke and have greater difficulty quitting smoking. In addition, an individual that meets the criteria for nicotine dependence is more likely to relapse." Depressed individuals are also more likely to smoke and have greater difficulty quitting smoking.

Based on the data collected, they know the dangers of smoking, as well as the source of the disease. Furthermore, it was found that 112 respondents $(83.17 \%)$ experienced shortness of breath due to smoking. According to the respondents, $66.7 \%$ visit the doctor, $77.04 \%$ bought medicine from the pharmacy, and $80.74 \%$ traditionally drank herbs and spices. According to DG, 16 years old, junior high school student, "I smoke to relieve stress because my parents have been fighting frequently since Covid-19, my younger siblings were crying, my mother did not cook for us to eat almost every day, and my father did not work, and therefore I asked my friends, relatives or work as a handyman between gallons of mineral water to smoke." Smoking behavior mainly affects physical activity and coping with stress but it is difficult to quit smoking. In this case, health promotion activities for smokers are influenced by work and the level of dependence and smoking habits [46].

Changes in smoking behavior were only detected in men who participated in the health examination program. In particular, those newly diagnosed with hyperlipidemia are more likely to quit and less likely to start smoking [47]. The community group at risk of mental disorders is a group of poor people. People with low income cannot meet their needs, living in poor conditions, and growing in a slum environment [48].

Environmental health behavior (PKL) has a significant and positive impact on economic pressure (TE). Therefore, an increase in environmental health behavior increases the economic pressure on adolescent smokers (Table 2).

"I realized that some of my friends were smoking, even taking drugs. First, it was only marijuana, then other types of drugs. Smoking is addictive, and therefore I am always busy looking for money to buy 
cigarettes, I do not go to school anymore. My brother advised me to be careful with my friends in such a way that I will not fall into drugs. He suggested that I look for friends that are healthy and have good behavior" (AM. 18 years old, did not graduate from high school, dropped out in the third grade, will take package C next year).

Cigarette smoke releases toxins, which are harmful to the environment and dangerous if inhaled directly by people nearby. The WHO advises countries to completely ban advertising, promotion, and cooperation from tobacco companies, because cigarette smoke releases toxins in environmental pollution [49]. It was found that $77.4 \%$ of the research stated that the rooms of adolescent smokers are stuffy and smoke a lot because apart from being in the room, they smoke in internet cafes and hang out with friends to play games. In such an environment, it is pleasant to smoke and drink soft drinks (95.56\%. Cigarette waste is disposed of carelessly, which pollutes the environment, only $21.48 \%$ of them throw their cigarette waste in the trash. According to ZP, 16 years old, junior high school student, "Our home environment is not clean, look... there is still a lot of garbage scattered and piled up. The residents have not been able to buy or make trash cans. The family who lives here are mediocre or cannot afford it." This is not much different from the research that was conducted in Tasikmalaya City [50]. It was found that socioeconomic status is related to the cleanliness of the environment, which means that the fulfillment of needs supported by the family's economic level will lead to behavior to maintain environmental cleanliness.

Global efforts to reduce the adverse effects of post-consumption tobacco waste on the environment are increasing, driven by concerns that over 1.69 billion pounds (720 million $\mathrm{kg}$ ) of cigarette butts end up as toxic waste each year [51]. Smoking not only damages the health of adolescents but also contributes to the environment in which air pollution occurs. The Tobacco Hazard Prevention Act in Taiwan stipulates that cigarettes may not be sold to people under the age of 18 [52]. This is almost similar to the research that showed that the cigarette filter is the most global and one of the main sources of marine pollution. Therefore, waste reduction is a serious challenge for policymakers and environmental authorities [53]. According to research conducted in Arab, it was recommended that smoking at home (1) strengthen the enforcement of smoking bans in workplaces and public places; (2) to increase public health education programs and campaigns on the adverse health effects of cigarette smoke on the environment; and (3) to develop and disseminate effective policies to promote smoke-free homes [54].

Healthy lifestyle behavior (PHS) has a significant and positive impact on economic pressure (TE). The increase in healthy lifestyle behavior gives rise to the economic Pressure on adolescent smokers in the City of Bengkulu (Table 2). The best choice is to be in a physically fit condition, without any complaints of severe illness or sluggish body, as well as having healthy and clean lifestyle behavior [5].

As stated before (TL, SD, 11 years old, having funk style), "I have been smoking since two years ago. I regret it, but cannot avoid it anymore because all my friends are smoking. My parents are divorced, and therefore I have been with my grandmother for 3 years. I often do not attend my online school because no one accompanies me to research. Covid-19 makes me happy because I do not need to go to school, we can sing for money and smoke while playing games together in internet cafes or cellphones. I have never exercised. Smoking makes me relieves stress since I often miss my mother." According to Runtukahu (2015), the lower the self-control of adolescents, the higher their smoking behavior. Therefore, a peer group is a factor that affects adolescent self-control. When most of the adolescent's peers smoke, the teen is more likely to smoke [55].

Economically, smoking makes people poor. Furthermore, in Indonesia, the consumption of cigarettes ranks second after rice, therefore having a significant impact on the poverty line [56]. Present and ex-smokers are exposed to many chronic diseases, but people that have never smoked inhales tobacco smoke are also at risk. In addition, smoking behavior and the associated disease risk are socially patterned and positively related to health inequalities [57].

Since smoking is the leading cause of death, it is important to prevent smoking, encourage cessation, and research factors that help individuals stay smokefree. A relevant factor is the influence of lifestyle on prolonged smoking cessation [58].

The SRB has a significant and positive effect on Economic Pressure (TE). Therefore, the increase in harmful behaviors gives rise to economic pressure on young smokers (Table 2). Other health issues caused by smoking are the wrinkled face, yellow teeth, defecation, bad breath, smelly environment, being a bad example for children, and becoming a gateway to the use of illegal drugs [59]. Furthermore, SN, a 16-year-old, 3rd-grade junior high school student stated "I have been smoking since 2 and half years ago. My body and breath smell bad. Moreover, since the Covid-19 holiday, I rarely take a bath, I am lazy to clean up myself. I often have a sore throat and went to Public Health Center, doctor or city hospital." In general, $94.81 \%$ of respondents know about health care facilities and free services for treatment because the respondent's family receives a health card from the government.

$A A$, an 18 years old, $2^{\text {nd }}$-grade senior high school student said "I have regular coughs and shortness of breath. I once recovered but often relapses. I once went to the Public Health Center, and the doctor told me not to smoke. It was difficult to quit smoking, and therefore, I never went to the Public Health Center again. I just 
endured the cough and shortness of breath, then it healed on its own. I smoke 8-12 cigarettes a day."

Those that smoke one cigarette per day is already at half the risk of heart disease and stroke, and therefore not only smoking and contact with other people increases the risk of cardiovascular disease [60]. The use of smokeless tobacco products also increases the risk of death from a heart attack or stroke. This is in line with the view expressed in previous research in Nigeria that all stakeholders should be involved in efforts to identify tobacco control strategies in adolescent and undergraduate students [3].

Minnesotan (United States) investments in extensive tobacco control measures have slowed the smoking rate. It saved billions in medical care and productivity costs and prevented tobacco-related diseases [61]. Furthermore, it is not much different from the smoke-free housing policy which has the potential to reduce exposure to cigarette smoke for residents of multi-unit housing. Since the common area is the path of movement of secondary smokers between units, a nonsmoking policy should reduce the number of secondary smokers in this microenvironment [62].

\section{Conclusion}

In Bengkulu City, adolescent smokers started smoking when they were 9 years old. Most are from a weak economic background in which the father worked as a construction worker with an average of 5 dependents in the family. The causes of smoking include friends, cheap cigarette prices, a lack of family control, no prohibitions, and the freedom to buy the cigarette for the children and teenagers. Furthermore, the research showed that Covid-19 does not make people stop smoking. They usually smoke in internet cafes when playing games in food stalls and using cell phones.

\section{References}

1. World Health Organization. Tobacco; 2021. Available from: https://www.who.int/news-room/fact-sheets/detail/tobacco. [Last accessed on 2021 Aug 30].

2. Sardana M, Goel S, Gupta M, Sardana V, Singh BS. Is exposure to tobacco advertising, promotion, and sponsorship associated with initiation of tobacco use among current tobacco users in youth in India? Asian Pac J Cancer Prev. 2015;16(15):6299302. https://doi.org/10.7314/apjcp.2015.16.15.6299 PMid:26434833

3. Oyewole BK, Animasahun VJ, Chapman HJ. Tobacco use in Nigerian youth: A systematic review. PLoS One. 2018;13(5):e0196362. https://doi.org/10.1371/journal. pone.0196362

PMid:29723203

4. Ramadani AC. Ini Penyebab Jumlah Perokok Anak Tinggi di Indonesia Republika Online. Republika; 2019. Available from: https://www.republika.co.id/berita/q0v52s463/ini-penyebabjumlah-perokok-anak-tinggi-di-indonesia. [Last accessed on 2021 Aug 17].

5. Kementerian Kesehatan RI. 10 Perilaku Hidup Bersih Dan Sehat di Rumah Tangga. Jakarta: Kementerian Kesehatan Kemenkes $\mathrm{Rl} ; 2017$.

6. Kemenkes RI. Hasil riset kesehatan dasar tahun 2018 Kementrian Kesehatan RI. 2019;53(9):1689-99. https://doi. org/10.32922/jkp.v8i1

7. Amani NK. WHO: 225.700 Orang Indonesia Meninggal Per Tahun Akibat Rokok-global Liputan. Indonesia: Natasha Khairunisa Amani. 2020;1-5.

8. Marhaeni H. Rokok Penyumbang Kemiskinan Terbesar Kedua di Indonesia. CNN Indonesia; 2018. Available from: https://www. cnnindonesia.com/ekonomi/20180130135917-532-272607/ rokok-penyumbang-kemiskinan-terbesar-kedua-di-indonesia. [Last accessed on 2021 Aug 17]. https://doi.org/10.23917/ reaksi.v3i1.5609

9. Pranita E. Jumlah Perokok di Indonesia Tinggi, Ahli Desak Pemerintah Lakukan 5 Hal Halaman all-Kompas. Kompas; 2020. Available from: https://www.kompas.com/sains/ $\mathrm{read} / 2020 / 09 / 25 / 200500823 / j u m l a h-p e r o k o k-d i-i n d o n e s i a-$ tinggi-ahli-desak-pemerintah-lakukan-5-hal?page=all. [Last accessed on 2021 Aug 17]. https://doi.org/10.22225/ kw.14.2.1845.103-109

10. Astuti NH, Barinda S, Hidayat TS. Perilaku merokok remaja lakilaki siswa smp swasta di depok smoking behavior among male adolescent on private junior high schools in Depok. Arkesmas. 2018;3(2):83-94. https://doi.org/10.22236/arkesmas.v3i2.2956

11. Kusumawardani N, Rachmalina, Wiryawan $\mathrm{Y}$, Anwar $\mathrm{A}$, Handayani K, Mubasyiroh R, et al. Perilaku Berisiko Kesehatan Pada Pelajar SMP Dan SMA Di Indonesia. Jakarta: Badan Litbangkes Kementrian Kesehatan Rl; 2015. https://doi. org/10.22435/mpk.v25i4.4589.227-234

12. Wardani Z, Sukandar D, Baliwati YF, Riyadi H. Akses sanitasi, merokok dan annual parasite incidence malaria sebagai prediktor stunting baduta di indonesia. Media Kesehatan Masyarakat Indonesia. 2020;16(1):127-39. https://doi.org/10.30597/mkmi. v16i1.9070

13. BPS. Persentase Merokok Pada Penduduk Umur $\geq 15$ Tahun Menurut Provinsi (Persen), 2018-2020. Badan Pusat Statistik 2020. Available from: https://www.bps.go.id/indicator/30/1435/1/ persentase-merokok-pada-penduduk-umur-15-tahun-menurutprovinsi.html. [Last accessed on 2021 Aug 17]. https://doi. org/10.29313/jstat.v19i2.5096

14. Antoni H. 301.814 Jiwa Hidup Miskin Beras dan Rokok Penyebab Utama. Bengkulu Ekspress; 2018. Available from: https://www. bengkuluekspress.com/301-814-jiwa-hidup-miskin-beras-danrokok-penyebab-utama. [Last accessed on 2021 Aug 17].

15. Usmin. Pemberlakuan Perda Bebas Rokok di Kota Bengkulu Belum Efektif; 2017. Available from: https://www.beritasatu. com/nasional/409064/pemberlakuan-perda-bebas-rokok-dikota-bengkulu-belum-efektif. [Last accessed on 2021 Aug 17]

16. Herlina M. Smoking: In local wisdom and social environment perspective. Ann Trop Med Public Health. 2018;9:1-15.

17. Al Ansori AN. Penularan COVID-19 Melalui Asap Rokok, Ini Jawaban IDI-Health. Liputan; 2020. Available from: https://www. liputan6.com/health/read/4227178/penularan-covid-19-melaluiasap-rokok-ini-jawaban-idi. [Last accessed on 2021 Aug 17].

18. Tohirin T. Metode Penelitian Kualitatif Dalam Pendidikan dan Bombingan Konseling. Jakarta: Raja Grafindo Persada; 2012.

19. Neuman WL. Metodologi Penelitian Sosial Pendekatan Kulitatif 
dan Kuantitatif. $7^{\text {th }}$ ed. Jakarta: PT Indeks; 2016.

20. Sugiyono S. Metode Penelitian Kualitatif. Bandung: Ababeta; 2021.

21. Martha E, Kresno S. Metodologi Penelitian Kualitatif, Untuk bidang kesehatan. Jakarta: PT RajaGrafindo Persada; 2016.

22. Yusuf M. Metode Penelitian Kuantitatif, Kualitatif and Penelitian Gabungan. Jakarta: Prenadamedia Group; 2014.

23. Miles BM, Huberman MA. Analisis Data Kualitatif. Jakarta: UI Press; 1992.

24. Wan X, Shin SS, Wang Q, Raymond HF, Liu H, Ding D, et al. Smoking among young rural to urban migrant women in China: A cross-sectional survey. PLoS One. 2011;6(8):1-7. https://doi. org/10.1371/journal.pone.0023028 PMid:21829683

25. He Y, Shang C, Chaloupka FJ. The association between cigarette affordability and consumption: An update PLoS One. 2018;13(12):e0200665. https://doi.org/10.1101/361287 PMid:30517093

26. Durandt JM, Bidjuni $\mathrm{H}$, Ismanto AY. Ubungan antara pola asuh orang tua dengan kebiasaan merokok anak usia remaja 12-17 tahun di desa kilometer tiga kecamatan Amurang. J Keperawatan UNSRAT. 2015;3(1):1-8. https://doi. org/10.23917/bik.v12i1.9618

27. Virga RL. Literasi iklan rokok dan perilaku konsumtif remaja melalui pemberdayaan remaja Masjid. Profetik J Komunikasi. 2016;9(2):33-44. https://doi.org/10.14421/pjk.v9i2.1201

28. Notoatmodjo S. IImu Perilaku Kesehatan. Jakarta: PT Rineka Cipta; 2010.

29. Yáñez AM, Leiva A, Estela A, Čukic I. The associations of personality traits and parental education with smoking behavior among adolescents. PLoS One. 2017;12(3):1-9. https://doi. org/10.1371/journal.pone.0174211

30. Yuliarti R, Karim D, Sabrian F. Hubungan perilaku merokok dengan prestasi belajar pada mahasiswa program studi ilmu Keperawatan Universitas Riau. J Online Mahasiswa. 2015;2(1):1-8. https://doi.org/10.33373/kop.v5i1.1449

31. Read UM, Karamanos A, Silva MJ, Molaodi OR, Enayat ZE, Cassidy $A$, et al. The influence of racism on cigarette smoking: Longitudinal study of young people in a British multi-ethnic cohort. PLoS One. 2018;13(1):1-26. https://doi.org/10.1371/ journal.pone.0190496 PMid:29364959

32. Ika. Guru Besar UGM Sebut Pandemi Covid-19 Jadi Momentum Berhenti Merokok, Universitas Gadjah Mada. UGM; 2020. Available from: https://www.ugm.ac.id/id/berita/19478-gurubesar-ugm-sebut-pandemi-covid-19-jadi-momentum-berhentimerokok. [Last accessed on 2021 Aug 17].

33. Gaiha SM, Cheng J, Halpern-Felsher B. Association Between Youth Smoking, Electronic Cigarette Use, and COVID-19. J Adolesc Health. 2020;67(4):519-23. https://doi.org/10.1016/j. jadohealth.2020.07.002 PMid:32798097

34. Ginting IR, Maulana R. Dampak kebiasaan merokok pada pengeluaran rumah Tangga. J Kebijakan Kesehatan Indonesia. 2020;9(2):77-82.

35. Baihaqi B. Defisit BPJS Kesehatan Akibat Pembiayaan Penyakit Karena Rokok. Harian Ekonomi Neraca; 2019. Available from: https://www.neraca.co.id/article/118461/defisit-bpjs-kesehatanakibat-pembiayaan-penyakit-karena-rokok. [Last accessed on 2021 Aug 17]. https://doi.org/10.20885/unisia.vol13.iss13.art6

36. Gendall P, Hoek J, Edwards R, McCool J. A cross-sectional analysis of how young adults perceive tobacco brands: Implications for FCTC signatories. BMC Public Health. 2012;12(1):1. https://doi.org/10.1186/1471-2458-12-796

37. Lawi GF. Astaga, Jumlah Perokok Anak dan Remaja
Meningkat-Lifestyle. India: BISNIS. 2020. Available from: https:// www.lifestyle.bisnis.com/read/20200603/106/1247944/astagajumlah-perokok-anak-dan-remaja-meningkat. [Last accessed on 2021 Aug 17]. https://doi.org/10.21070/2021/978-623-6292-00-6

38. Lidwina A. Meski pandemi covid-19, $77 \%$ warga miskin tak Turunkan Konsumsi Rokok, Databoks. Databoks; 2021. Available from: https://www.databoks.katadata.co.id/ datapublish/2021/07/04/meski-pandemi-covid-19-77-wargamiskin-tak-turunkan-konsumsi-rokok. [Last accessed on 2021 Aug 17]. https://doi.org/10.31234/osf.io/7vek9

39. Ruhyat E. Perilaku merokok di masa covid 19. Sehat Masada. 2021;15(1):180-7.

40. Tidey JW. A behavioral economic perspective on smoking persistence in serious mental illness. Prev Med. 2016;92(1):315. https://doi.org/10.1016/j.ypmed.2016.05.015 PMid:27196141

41. Global Tobacco Economics Consortium. The health, poverty, and financial consequences of a cigarette price increase among 500 million male smokers in 13 middle-income countries: A compartmental model study. BMJ. 2018;361:k1162. https:// doi.org/10.1136/bmj.k1162

42. Fiore MC, Baker TB. Treating smokers in the health care setting Michael. N Engl J Med. 2011;365(13):1222-31. PMid:21991895

43. Gritz ER, Talluri R, Fokom Domgue J, Tami-Maury I, Shete S. Smoking behaviors in survivors of smoking-related and nonsmoking-related cancers. JAMA Netw Open. 2020;3(7):1-16. https://doi.org/10.1001/jamanetworkopen.2020.9072 PMid:32614423

44. Jung M. Exploring socio-contextual factors associated with male smoker's intention to quit smoking. BMC Public Health. 2016;16(1):1-8. https://doi.org/10.1186/s12889-016-3054-5 PMid:27178199

45. Weinberger AH, Kashan RS, Shpigel DM, Esan H, Taha F, Lee CJ et al. Depression and cigarette smoking behavior: A critical review of population-based studies. Am J Drug Alcohol Abuse. 2016;43(4):416-31. https://doi.org/10.3109/00952990.2016. 1171327

PMid:27286288

46. Kafadar D, Esen AD, Arıca S. Determining health-promoting behavior in smokers preparing to quit: A holistic and personalized approach. EPMA J. 2019;10(2):115-23. https://doi.org/10.1007/ s13167-019-00172-3

PMid:31258817

47. Kwon JA, Jeon W, Park EC, Kim JH, Kim SJ, Yoo KB, et al Effects of disease detection on changes in smoking behavior. Yonsei Med J. 2015;56(4):1143-9. https://doi.org/10.3349/ ymj.2015.56.4.1143

PMid:26069141

48. Dharmayanti I, Tjandrarini DH, Hidayangsih PS, Nainggolan O Pengaruh kondisi kesehatan lingkungan dan sosial ekonomi terhadap kesehatan mental di Indonesia. J Ekol Kesehatan. 2018;17(2):64-74. https://doi.org/10.22435/jek.17.2.149.64-74

49. World Health Organization Tobacco and Its Environmental Impact: An Overview. Geneva: World Health Organization; 2017. P. 72.

50. Nurjanah N, Fitri S, Febrian K. Hubungan status sosial ekonomi dan motivasi hidup sehat dengan perilaku memelihara kebersihanlingkungan (studi pada lbu rumah tangga RW 05 kelurahan setiaratu kecamatan cibeureum kota Tasikmalaya). Edun J Pendidikan Ekon. 2018;6(1):36-40. https://doi. org/10.33603/ejpe.v6i1.1010

51. Kassem NO, Kassem NO, Liles S, Reilly E, Kas-Petrus F, Posis Al, et al. Waterpipe device cleaning practices and disposal of waste associated with waterpipe tobacco smoking in homes 
in the USA. Tobacco Control. 2019;29(2):123-30. https://doi. org/10.1136/tobaccocontrol-2019-054959

PMid:31326957

52. Chen ML, Chou LN, Zheng YC. Providing a clean environment for adolescents: Evaluation of the tobacco hazards prevention act in Taiwan. Int J Environ Res Public Health. 2017;14(6):1-11. https://doi.org/10.3390/ijerph14060634

PMid:28608829

53. Castaldi G, Cecere G, Zoli M. "Smoke on the Beach": On the use of economic vs behavioral policies to reduce environmental pollution by cigarette littering. Econ Pol. 2020;38:1025-48.

54. Berman T, Barnett-Itzhaki Z, Mery N, Keinan-Boker L, Shimony T, Goldsmith R, et al. Exposure to environmental tobacco smoke in non-smoking adults in Israel: Results of the second Israel biomonitoring survey. Israel J Health Policy Res. 2018;7(1):1-7.

55. Wibowo M. Perspektif hambatan terhadap kemungkinan remaja berhenti merokok Marsiana. Unnes J Public Health. 2017;6(2):137-40.

56. Almizi M, Hermawati I. Upaya pengentasan kemiskinan dengan mengurangi konsumsi rokok di Indonesia the effort of poverty alleviation by reducing cigarettes consumption in Indonesia. J Penelitian Evaluasi Pendidikan. 2018;17(3):239-56.
57. Eberth B, Olajide D, Craig P, Ludbrook A. Smoking-related disease risk, area deprivation, and health behaviors. J Public Health. 2014;36(1):72-80. https://doi.org/10.1093/pubmed/ fdt031

PMid:23554509

58. Sohlberg T, Bergmark KH. Lifestyle and long-term smoking cessation. Tobacco Use Insights. 2020;13:2096306.

59. Nururrahmah H. Pengaruh rokok terhadap kesehatan dan pembentukan karakter Manusia. Prosid Sem Nasional. 2014;1(1):78

60. World Health Organization. The Tobacco Body. Geneva: World Health Organization; 2019. Available from: https://www. apps.who.int/iris/handle/10665/324846. [Last accesed on 2020 Oct 04]

61. Maciosek MV, Lafrance $A B$, St Claire $A, X u Z$, Brown $M$, Schillo BA. Twenty-year health and economic impact of reducing cigarette use: Minnesota 1998-2017. Tobacco Control. 2020;29(5):564-9.

62. MacNaughton P, Adamkiewicz G, Arku RE, Vallarino J, Levy DE. The impact of a smoke-free policy on environmental tobacco smoke exposure in public housing developments. Sci Total Environ. 2016;557-558:676-80. https://doi.org/10.1016/j. scitotenv.2016.03.110 